\title{
COLOR VARIABILITY AND RELATIONSHIP WITH BASIC DENSITY AND EXTRACTIVE CONTENT OF Calycophyllum spruceanum WOOD
}

\author{
Sandra Bezerra da Silva ${ }^{1}$, Jaily Kerller Batista de Andrade ${ }^{2 *}$, Marina Donária Chaves Arantes ${ }^{3}$, João Gabriel \\ Missia da Silva ${ }^{2}$, Victor Fassina Brocco², Juarez Benigno Paes ${ }^{4}$ \\ ${ }^{1}$ Federal University of Acre, Graduate Program in Plant Production, Rio Branco, Acre, Brazil - sandrinha.czs@ hotmail.com \\ ${ }^{2 *}$ Federal University of Espírito Santo, Graduate Program in Forest Sciences, Jerônimo Monteiro, Espirito Santo, Brazil - \\ jaily.10@hotmail.com*,j.gabrielmissia@hotmail.com, vfbrocco@hotmail.com, respectively \\ ${ }^{3}$ Federal University of São João Del Rei, Forestry Engineering Department, Sete Lagoas, Minas Gerais, Brazil - mdonariac@ufsj.edu.br \\ ${ }^{4}$ Federal University of Espírito Santo, Department of Forestry and Wood Sciences, Jerônimo Monteiro, Espírito Santo, Brazil - \\ jbp2@uol.com.br
}

Received on: 10/05/2018 - Accepted on: 27/02/2019

\begin{abstract}
Resumo
Variabilidade da cor e relação com a densidade básica e teor de extrativos da madeira de pau-mulato (Calycophyllum spruceanum). Existem relatos relacionando a cor aos extrativos, no entanto há carência de informações sobre o efeito de outras características na colorimetria da madeira. Assim, o objetivo do estudo foi avaliar a variabilidade longitudinal e radial da cor e sua relação com a densidade básica e teor de extrativos da madeira de pau-mulato (Calycophyllum spruceanum), de plantio com idade de seis anos, localizado em Rio Branco, Acre. A determinação e avaliação da cor da madeira foram realizadas pelo sistema da Commission Internationale de L'Éclairage - CIE-L*a* $\mathrm{b}^{*}$. A densidade básica e o teor de extrativos foram determinados conforme normas técnicas vigentes. A cor da madeira da espécie foi classificada como oliva amarelado. No sentido longitudinal, a maior e menor luminosidades $\left(\mathrm{L}^{*}\right)$ da madeira foram observadas na base (altura de corte) e no diâmetro a altura do peito - DAP, tomado a $1,30 \mathrm{~m}$ da superfície do solo, respectivamente. Em relação à posição radial, a luminosidade $\left(\mathrm{L}^{*}\right)$ foi menor nas regiões periféricas do fuste. As maiores concentrações do matiz vermelho $\left(a^{*}\right)$ e amarelo ( $\left.b^{*}\right)$ e da saturação $(C)$ ocorreram longitudinalmente no DAP e na posição radial externa. Na idade avaliada, o teor de extrativos não teve relação com a cor da madeira, enquanto a densidade básica relacionou-se com os parâmetros colorimétricos $\mathrm{a}^{*}, \mathrm{~b}^{*}, \mathrm{C}$ e h*. A caracterização colorimétrica da espécie contribui para a sua adequada identificação e para a classificação mais homogênea de peças serradas, podendo ser utilizada desde o desdobro da tora, até o aproveitamento final, agregando valor comercial à madeira.

Palavras-chave: Colorimetria, sistema CIE-L*a*b*, espécie tropical, qualidade da madeira.
\end{abstract}

\begin{abstract}
There are reports relating color to extractives, however there is a lack of information about the effect of other characteristics on the colorimetry of wood. Thus, this study aimed to evaluate the longitudinal and radial variability of color and its relationship with the basic density and extractive contents of Calycophyllum spruceanum wood from a six-year-old plantation located in Rio Branco, Acre, Brazil. The determination and assessment of the wood color were carried out by the Commission Internationale de L'Éclairage - CIE-L*a*b* system. The basic density and extractive contents were determined according to current technical standards. The species wood color was classified as yellowish olive. The highest and lowest lightness ( $\mathrm{L}^{*}$ ) were longitudinally observed in the base (cutting height) and diameter at breast height (DBH), taken at $1.30 \mathrm{~m}$ from the ground. In relation to radial position, the lightness $\left(\mathrm{L}^{*}\right)$ was lower in peripheral regions of the trunk. Higher concentrations of redness $\left(\mathrm{a}^{*}\right)$ and yellowness $\left(\mathrm{b}^{*}\right)$ and saturation $(\mathrm{C})$ occurred along the DBH and the external radial position. In evaluating age, the extractive contents were not correlated to the wood color, while the basic density was correlated with $\mathrm{a}^{*}, \mathrm{~b}^{*}, \mathrm{C}$ and $\mathrm{h}^{*}$ colorimetric parameters. The colorimetric characterization of this specie contributes to its proper identification and a more homogeneous classification of lumber, and can be used from the log break-down (sawing) to its end use, adding commercial value to the wood.

Keywords: Colorimetry, CIE-L*a*b* system, tropical species, wood quality.
\end{abstract}

\section{INTRODUCTION}

Several forest species occurring in the Amazon Region are scientifically known and marketed for their potential as wood producers. However, others are not cataloged and need studies which will contribute to the knowledge about their characteristics. The lack of studies on the potential of plant species in the region makes the Amazon biome a target for biopiracy and predatory extraction of timber and non-timber resources (SANTOS et al., 2016).

Among species of the Amazonian biome with commercial importance is Calycophyllum spruceanum Benth., belonging to the Rubiaceae family, with fast growth, large size, and high potential for natural regeneration

FLORESTA, Curitiba, PR, v. 49, n. 4, p. 803 - 812, out/dez 2019.

Silva, S. B. et.al.

ISSN eletrônico 1982-4688

DOI: $10.5380 /$ rf.v49 i4.59374 
(SOTELO MONTES et al., 2008). The species is indicated for the recovery of degraded areas and reforestation Due to its low demand on soil fertility and allied to these characteristics (MARANHO et al., 2013).

Due to its physicochemical and mechanical characteristics, wood is used for producing handles for tools, picture and housing frames, floors, civil construction and furniture manufacturing (UGARTE-GUERRA; DOMÍNGUEZ-TORREJÓN, 2010), joinery in general, fencing/fence posts, firewood and charcoal. In addition to these uses, the species is researched for pharmacological and phytochemical purposes (PEIXOTO et al., 2018).

Although considered a species of economic value, little is known about the wood properties of C. spruceanum (native or from forest plantations). Therefore, characterizing the wood of this species at young ages is important, since trees smaller than $50 \mathrm{~cm}$ in diameter produce wood with good dimensional stability (Araújo et al., 2016). Based on this, knowledge of wood characteristics from planting management (thinning) is important to meet the market demand and to diagnose the effects of growth conditions on wood quality and calorimetry.

Thus, in addition to contributing to scientific knowledge, determining the color of $C$. spruceanum wood will enable a comparison with other traditional forest species, as well as the uniformity and aggregation of value in the commercialization of solid or wood products. Thus, color becomes one of the most important characteristics for the classification, identification and indication of forest species uses and is associated with the surface quality and design of a piece of wood (CAMARGOS; GONÇALEZ, 2001, GARCIA et al., 2014). For these reasons, and the growing market demand for better quality products, this feature must be incorporated into the technological characterization of wood and production planning, aiming to meet the guidelines of higher added value uses (MORI et al., 2004).

According to Camargos and Gonçalez (2001), there are some factors which can change the color of the wood such as; moisture, temperature, deterioration caused by xylophagous organisms or even photochemical reactions of the chemical components present in its structure. The trees' age is also a factor which influences the natural color of this material, as well as the silvicultural traits and the soil type where the plant developed (SOTELO MONTES et al., 2008).

The coloration attribute of a wood only by visual analysis is subjective, since the color may be classified differently depending on the observer and the luminosity. Thus, quantitative methods have been developed to circumvent this which employ numerical variables for light-induced interactions on a surface (SILVA et al., 2015).

Colorimetry is an efficient methodology for color measurement which enables its classification with the help of color coordinates, aiming to add value to little known forest species, improve the price of this material in the Market and make the product more homogeneous; it is additionally a relevant criterion when buying wood products (GONÇALEZ et al., 2001; MORI et al., 2004).

The Commission Internationale de L'Éclairage (CIE) is one of the most widely used systems for color measurement and is based on three elements: brightness or clarity, tone or hue, and saturation or chromaticity. These elements are obtained through the $\mathrm{L}^{*},+\mathrm{a}^{*},-\mathrm{a}^{*},+\mathrm{b}^{*},-\mathrm{b}^{*}$ and $\mathrm{C}$ colorimetric parameters. In this system, $\mathrm{L}^{*}$ indicates the lightness and ranges between 0 and 100 , where 0 represents pitch black and 100 total white. The $\mathrm{a}^{*}$ indicates the red-green hue, where the positive number indicates red and the negative green. The $b^{*}$ indicates the yellow-blue hue, with the positive number corresponding to yellow and the negative to blue. Saturation (C) indicates color purity, while $\mathrm{h} *$ corresponds to the hue angle.

The use of this tool for determining the color of tropical woods is important in adding value to species, especially non-traditional species in the national or international market (ZANUNCIO et al., 2014). In this context, considering the lack of studies on the colorimetry of little known species in international trade, the objective of this study was to evaluate the longitudinal and radial color variability, as well as its relationship with the basic density and extractives content of Calycophyllum spruceanum wood.

\section{MATERIAL AND METHODS}

\section{Species identification and location of collection area}

The trees used in this study came from an experimental six-year-old Calycophyllum spruceanum Benth. plantation of the Brazilian Agricultural Research Corporation - EMBRAPA Acre, in Rio Branco, located in the extreme southwest of the Brazilian Amazon. The plantation (300 trees planted in $3 \times 2 \mathrm{~m}$ spacing) is located between the geographic coordinates of $10^{\circ} 01^{\prime} 22^{\prime \prime}$ and $10^{\circ} 04^{\prime} 14^{\prime \prime}$ South latitude and of $67^{\circ} 40^{\prime} 3^{\prime \prime}$ and $67^{\circ} 42^{\prime} 43^{\prime \prime}$ West longitude of Greenwich.

Five random trees were selected, and six discs $(3 \mathrm{~cm}$ thick) were removed after their cutting in diameter at breast height (DBH) taken at $1.30 \mathrm{~m}$ from the ground surface, and at $0.25,50,75$ and $100 \%$ of the average commercial height, which was approximately six meters. The discs were air dried and used in all technological analyzes. 


\section{Wood color measurement}

The CIE-L* a* b* method (1976) was used to measure the wood color by using a Konica Minolta CM2500D spectrophotometer with standard D65 illuminant, $10^{\circ}$ observation angle and including specular light. The equipment was calibrated with black and white standard and a calibrating plate of the equipment itself was used for calibrating the white standard.

Prior to colorimetric analysis, the disc surface was polished with a sequence of 80 and 150 grit sandpaper and stored in dark plastic bags out of contact from light. The color measurement was performed in the cross-section in the marrow-to-bark direction. Twelve measurements were performed, equidistant from the marrow in each of the samples (Figure 1), totaling 360 measurements (five trees, six discs per tree and 12 measurements per disc). The number of measurements per disc met the recommendation of Camargos and Gonçalez (2001), who found that the variance of color parameters becomes constant above 10 measurements.

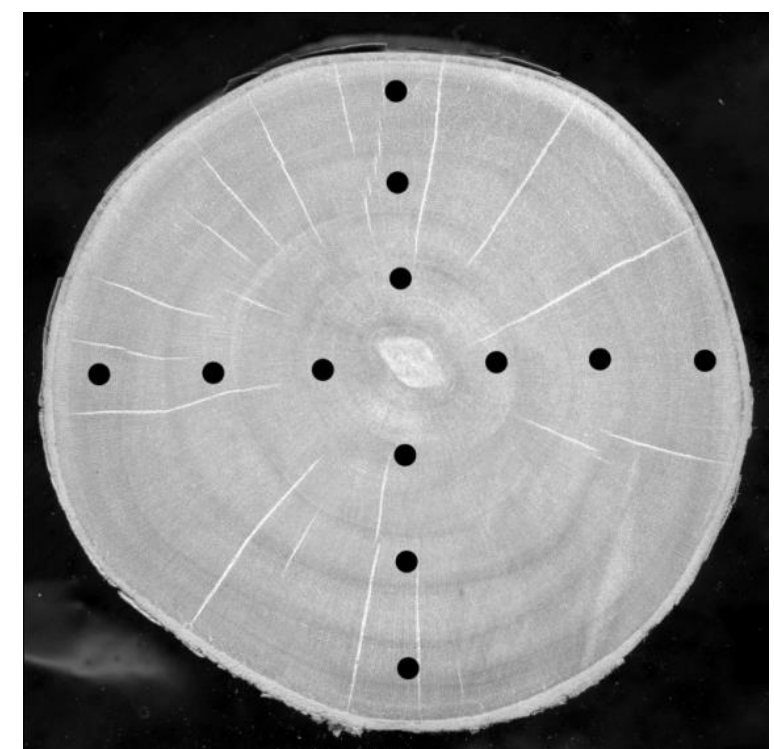

Figure 1. Transverse surface of Calycophyllum spruceanum wood, showing the color reading points.

Figura 1. Superfície transversal do lenho de Calycophyllum spruceanum, demonstrando os pontos de leitura da cor.

The colorimetric parameters evaluated were lightness $\left(\mathrm{L}^{*}\right)$, the red-green coordinate or redness $\left(\mathrm{a}^{*}\right)$ and the blue-yellow coordinate or yellowness (b*), based on the CIE-L* a* b* System (1976). Saturation (C) and hue angle $\left(\mathrm{h}^{*}\right)$ were calculated by the following formulas:

$$
\begin{aligned}
& \mathrm{C}=\left(\mathrm{a}^{* 2}+\mathrm{b}^{* 2}\right)^{0.5} \\
& \mathrm{~h}^{*}=\tan ^{-1}\left(\frac{\mathrm{b}^{*}}{\mathrm{a}^{*}}\right)
\end{aligned}
$$

where: (C) the saturation, $\left(a^{*}\right)$ the chromatic coordinate of the green-red axis, $\left(b^{*}\right)$ the chromatic coordinate of the blue-yellow axis, and $\left(h^{*}\right)$ the hue angle.

\section{Determining basic density and wood extractives content}

The basic wood density was determined along the trunk following the specifications of the Brazilian Regulatory Standard - NBR 11941 of the Brazilian Association of Technical Standards - ABNT (2003). Specimens of $2 \times 2 \times 3 \mathrm{~cm}$ (radial $\times$ tangential x longitudinal) dimensions were taken radially from each disc of each position, thereby totaling 30 samples - one for each tree and position along the trunk.

Opposing wedges were removed from the disc of each longitudinal position of the commercial trunk, sawn, crushed and sieved, and the fraction that passed through the 40 mesh was retained in the 60 mesh. The analysis was performed by using a tree sample. This methodology was used due to the amount of wood available for the analyzes. The extractives content in ethanol:toluene (2:1 ratio) was obtained according Technical Association of the Pulp and Paper Industry - TAPPI 264 om-88 (1992), with the analyzes being performed in duplicates.

FLORESTA, Curitiba, PR, v. 49, n. 4, p. 803 - 812, out/dez 2019. 


\section{Statistical analysis}

A completely randomized design was used in a $6 \times 3$ factorial scheme (longitudinal $\mathrm{x}$ radial position), as well as an analysis of variance and the F-test to evaluate the effects of longitudinal (0, DBH, 25, 50, 75 and $100 \%$ ) and radial (internal, intermediate and external) position factors on the variation of colorimetric parameters. Significant factors by the F-test $(\mathrm{p}<0.05)$ were analyzed by the Scott-Knott test $(\mathrm{p}<0.05)$. Assumptions of variance homogeneity and data normality were verified by the Bartlett and Shapiro-Wilk tests, respectively. The effect of one colorimetric parameter on the other and the relationship of extractives content and basic density with the wood color was evaluated by a Pearson correlation analysis and its p-value (F-test).

\section{RESULTS}

Colorimetric characterization and wood color variability

The mean values for the colorimetric parameters in the $C$. spruceanum wood were in the order of $\mathrm{L}^{*}=$ $66.31 ; \mathrm{a}^{*}=6.68 ; \mathrm{b}^{*}=20.94 ; \mathrm{C}=22.02 ;$ and $\mathrm{h}^{*}=72.51$, which enabled classifying its color as yellowish-olive (CAMARGOS; GONÇALEZ, 2001). These varied along the trunk and in the medulla-bark direction (Table 1).

Table 1. Summary of analysis of variance for the colorimetric parameters of six-year-old Calycophyllum spruceanum wood for the longitudinal and radial positions in the trunk.

Tabela 1. Resumo da análise de variância para os parâmetros colorimétricos da madeira de Calycophyllum spruceanum, com seis anos, para as posições longitudinais e radiais no tronco.

\begin{tabular}{ccccccc}
\hline \multirow{2}{*}{ Variation source } & \multirow{2}{*}{$\begin{array}{c}\text { Degrees of } \\
\text { freedom }\end{array}$} & $\mathbf{L}$ & $\mathbf{a}^{*}$ & $\mathbf{b}^{*}$ & $\mathbf{C}$ & $\mathbf{h}^{*}$ \\
\cline { 3 - 7 } & 5 & $268.78^{* *}$ & $47.54^{* *}$ & $69.20^{* *}$ & $97.62^{* *}$ & $131.60^{* *}$ \\
Longitudinal position (L) & 2 & $154.48^{* *}$ & $57.32^{* *}$ & $103.34^{* *}$ & $142.13^{* *}$ & $117.15^{* *}$ \\
Radial position (R) & 10 & $4.17^{\text {ns }}$ & $6.19^{* *}$ & $7.08^{*}$ & $10.70^{* *}$ & $17.45^{*}$ \\
L x R & 342 & 8.53 & 1.98 & 3.08 & 3.83 & 8.56 \\
Residual & &
\end{tabular}

Legend: **Significant $(\mathrm{p} \leq 0.01)$; *significant $(\mathrm{p} \leq 0.05)$; ${ }^{\text {ns }}$ not significant $(\mathrm{p}>0.05)$ by the F-test.

The highest and lowest lightness (Figure 2) in the longitudinal direction of the $C$. spruceanum wood were observed in the base positions $(0 \%)$ and $\mathrm{DBH}$, respectively. Regarding the radial position, the $\mathrm{L}^{*}$ value was decreasing $\left(3.20 \%\right.$ or $\left.\Delta \mathrm{L}^{*}=-2.15\right)$ from medulla to bark.

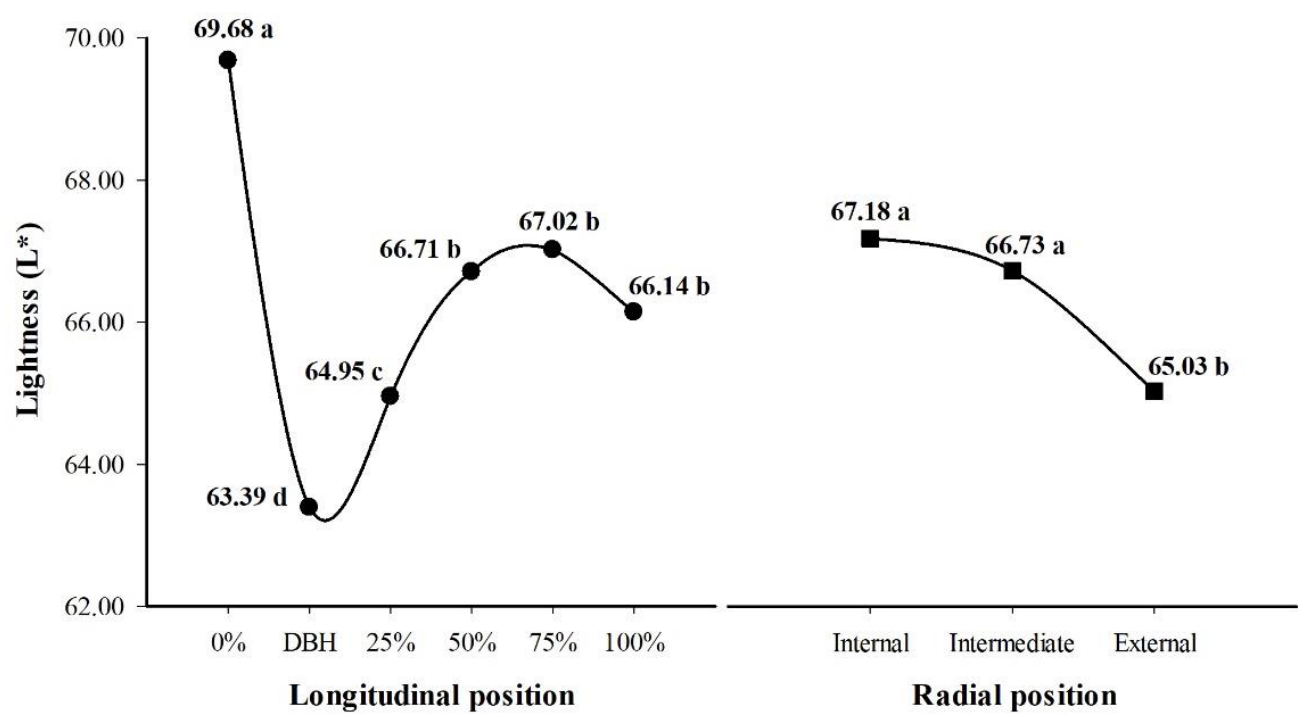

Figure 2. Longitudinal and radial lightness ( $\left.\mathrm{L}^{*}\right)$ variability of six-year-old Calycophyllum spruceanum wood for the trunk positions.

Figura 2. Variabilidade longitudinal e radial da luminosidade (L*) da madeira de Calycophyllum spruceanum, seis anos, para as posições no tronco.

Variations in the $\mathrm{a}^{*}, \mathrm{~b}^{*}$ and $\mathrm{C}$ colorimetric parameters were similarly observed for the internal and intermediate regions within each longitudinal position of the C. spruceanum wood (Table 2). 
Table 2. Multiple mean comparison of $\mathrm{a}^{*}, \mathrm{~b}^{*}, \mathrm{C}$ colorimetric parameters and $\mathrm{h}^{*}$ of six-year-old Calycophyllum spruceanum wood for the trunk positions.

Tabela 2. Comparações múltiplas das médias dos parâmetros colorimétricos $\mathrm{a}^{*}, \mathrm{~b}^{*}, \mathrm{C}$ e $\mathrm{h}^{*}$ da madeira de Calycophyllum spruceanum com seis anos, para as posições no tronco.

\begin{tabular}{|c|c|c|c|}
\hline \multicolumn{4}{|c|}{ a* Chromatic coordinate } \\
\hline \multirow{2}{*}{ Longitudinal position } & \multicolumn{3}{|c|}{ Radial position } \\
\hline & Internal & Intermediate & External \\
\hline $0 \%$ & $6.31 \mathrm{Bb}$ & $7.81 \mathrm{Aa}$ & 8.31 Aa \\
\hline $\mathrm{DBH}$ & $7.03 \mathrm{Ba}$ & $7.63 \mathrm{Ba}$ & $8.93 \mathrm{Aa}$ \\
\hline $25 \%$ & $5.94 \mathrm{Bb}$ & $6.50 \mathrm{Bb}$ & $8.34 \mathrm{Aa}$ \\
\hline $50 \%$ & $5.52 \mathrm{Bb}$ & $6.15 \mathrm{Bb}$ & $7.18 \mathrm{Ab}$ \\
\hline $75 \%$ & $6.01 \mathrm{Ab}$ & $5.83 \mathrm{Ab}$ & $5.99 \mathrm{Ac}$ \\
\hline $100 \%$ & $5.68 \mathrm{Ab}$ & $5.26 \mathrm{Ab}$ & $5.87 \mathrm{Ac}$ \\
\hline \multicolumn{4}{|c|}{ b* Chromatic coordinate } \\
\hline \multirow{2}{*}{ Longitudinal position } & \multicolumn{3}{|c|}{$\begin{array}{l}\text { Radial position } \\
\end{array}$} \\
\hline & Internal & Intermediate & External \\
\hline $0 \%$ & $19.58 \mathrm{Bb}$ & $22.19 \mathrm{Aa}$ & $22.23 \mathrm{Ab}$ \\
\hline $\mathrm{DBH}$ & $21.76 \mathrm{Ba}$ & $22.68 \mathrm{Ba}$ & $24.02 \mathrm{Aa}$ \\
\hline $25 \%$ & $19.88 \mathrm{Bb}$ & $20.88 \mathrm{Bb}$ & $22.37 \mathrm{Ab}$ \\
\hline $50 \%$ & $19.34 \mathrm{Bb}$ & $20.28 \mathrm{Bb}$ & $21.80 \mathrm{Ab}$ \\
\hline $75 \%$ & $19.46 \mathrm{Ab}$ & $20.12 \mathrm{Ab}$ & $20.21 \mathrm{Ac}$ \\
\hline $100 \%$ & $19.82 \mathrm{Ab}$ & $19.94 \mathrm{Ab}$ & $20.32 \mathrm{Ac}$ \\
\hline \multicolumn{4}{|c|}{ Saturation $(\mathbf{C})$} \\
\hline \multirow{2}{*}{ Longitudinal position } & \multicolumn{3}{|c|}{$\begin{array}{r}\text { Radial position } \\
\end{array}$} \\
\hline & Internal & Intermediate & External \\
\hline $0 \%$ & $20.60 \mathrm{Bb}$ & $23.55 \mathrm{Aa}$ & $23.75 \mathrm{Ab}$ \\
\hline $\mathrm{DBH}$ & $22.89 \mathrm{Ba}$ & $23.95 \mathrm{Ba}$ & $25.64 \mathrm{Aa}$ \\
\hline $25 \%$ & $20.78 \mathrm{Bb}$ & $21.90 \mathrm{Bb}$ & $23.89 \mathrm{Ab}$ \\
\hline $50 \%$ & $20.13 \mathrm{Bb}$ & $21.23 \mathrm{Bb}$ & $22.97 \mathrm{Ab}$ \\
\hline $75 \%$ & $20.41 \mathrm{Ab}$ & $20.98 \mathrm{Ab}$ & $21.09 \mathrm{Ac}$ \\
\hline $100 \%$ & $2067 \mathrm{Ab}$ & $20.66 \mathrm{Ab}$ & $21.19 \mathrm{Ac}$ \\
\hline \multicolumn{4}{|c|}{ Hue angle $\left(h^{*}\right)$} \\
\hline \multirow{2}{*}{ Longitudinal position } & \multicolumn{3}{|c|}{ Radial position } \\
\hline & Internal & Intermediate & External \\
\hline $0 \%$ & $72.21 \mathrm{Aa}$ & $70.61 \mathrm{Bc}$ & $69.54 \mathrm{Bc}$ \\
\hline $\mathrm{DBH}$ & $72.17 \mathrm{Aa}$ & $71.45 \mathrm{Ac}$ & $69.60 \mathrm{Bc}$ \\
\hline $25 \%$ & $73.61 \mathrm{Aa}$ & $72.86 \mathrm{Ab}$ & $69.58 \mathrm{Bc}$ \\
\hline $50 \%$ & $74.09 \mathrm{Aa}$ & $73.27 \mathrm{Ab}$ & $71.86 \mathrm{Ab}$ \\
\hline $75 \%$ & $73.10 \mathrm{Aa}$ & $74.00 \mathrm{Ab}$ & $73.58 \mathrm{Aa}$ \\
\hline $100 \%$ & $74.12 \mathrm{Aa}$ & $75.45 \mathrm{Aa}$ & $74.15 \mathrm{Aa}$ \\
\hline
\end{tabular}

The means followed by the same letter (upper and lower case) do not differ statistically by the Scott-Knott test ( $>>0.05$ ). 


\section{Relationships of extractives content and basic density with wood color}

The extractives content (EC) in toluene ethanol was not related to the $C$. spruceanum wood color, which can be confirmed by the absence of significant correlations between this chemical property and colorimetric parameters (Figure 3). The highest correlation coefficient value, although weak, was observed between EC and $\mathrm{L}^{*}$.

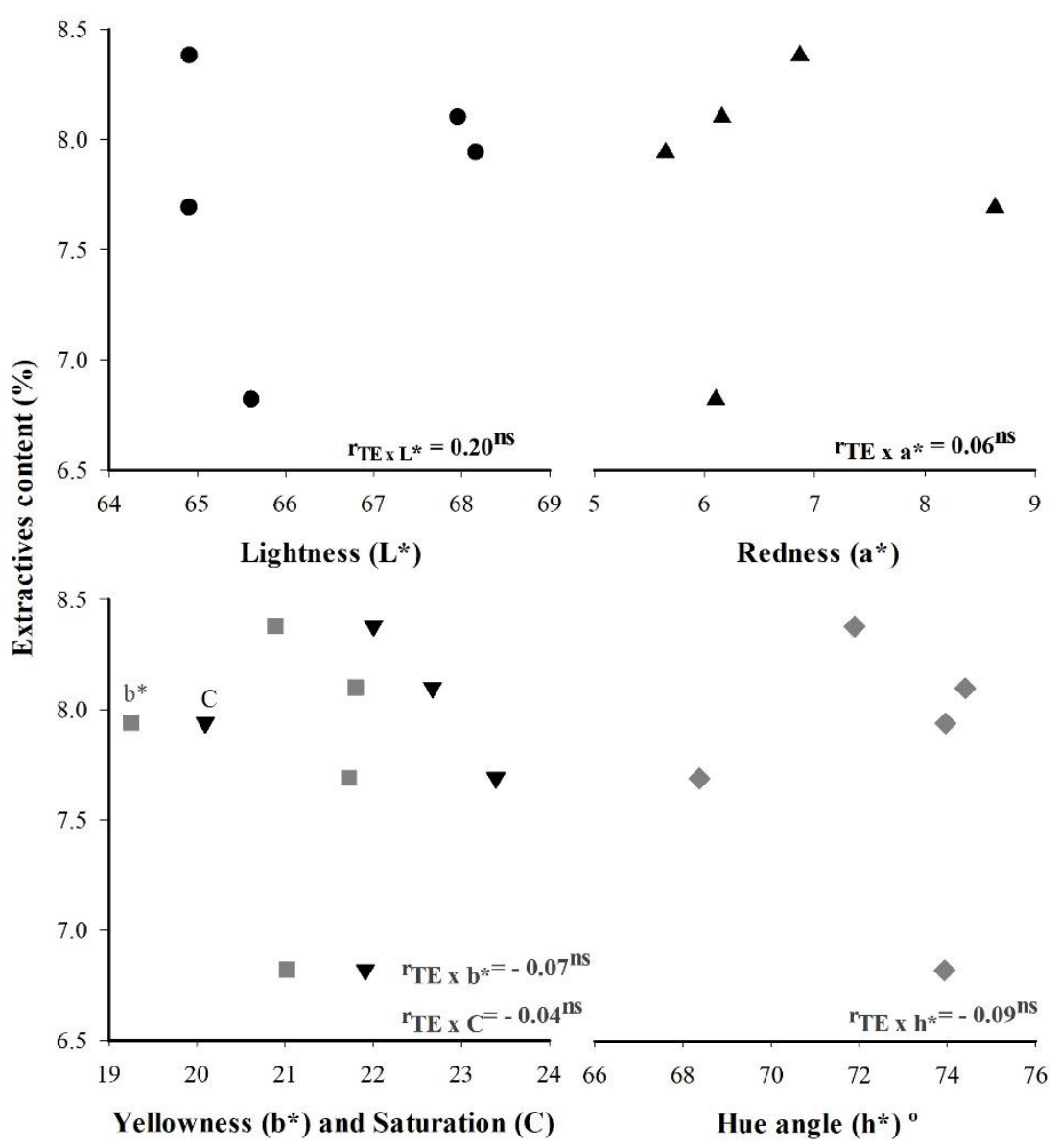

Legend: EC, extractives content; ${ }^{\text {ns }}$, not significant $(\mathrm{p}>0.05)$.

Figure 3. Correlations between the extractive contents and colorimetric parameters $\left(\mathrm{L}^{*}, \mathrm{a}^{*}, \mathrm{~b}^{*}, \mathrm{C}^{*}\right.$ and $\left.\mathrm{h}^{*}\right)$ of sixyear-old Calycophyllum spruceanum wood.

Figura 3. Correlações entre o teor de extrativos e os parâmetros colorimétricos $\left(L^{*}, a^{*}, b^{*}, C\right.$ e $\left.h^{*}\right)$ da madeira de Calycophyllum spruceanum, com seis anos de idade.

For the correlations between colorimetric parameters and wood density (Figure 4), it is noted that the higher the yellow and red pigmentation and the saturation of these colors, the higher the basic density (BD) of the wood. This relationship is elucidated by the positive median and significant correlations observed between the BD and the $\mathrm{a}^{*}, \mathrm{~b}^{*}$ and $\mathrm{C}$ coordinates. The lightness was not related to the basic wood density, since there was no significant correlation between $\mathrm{BD}$ and $\mathrm{L}^{*}$. 

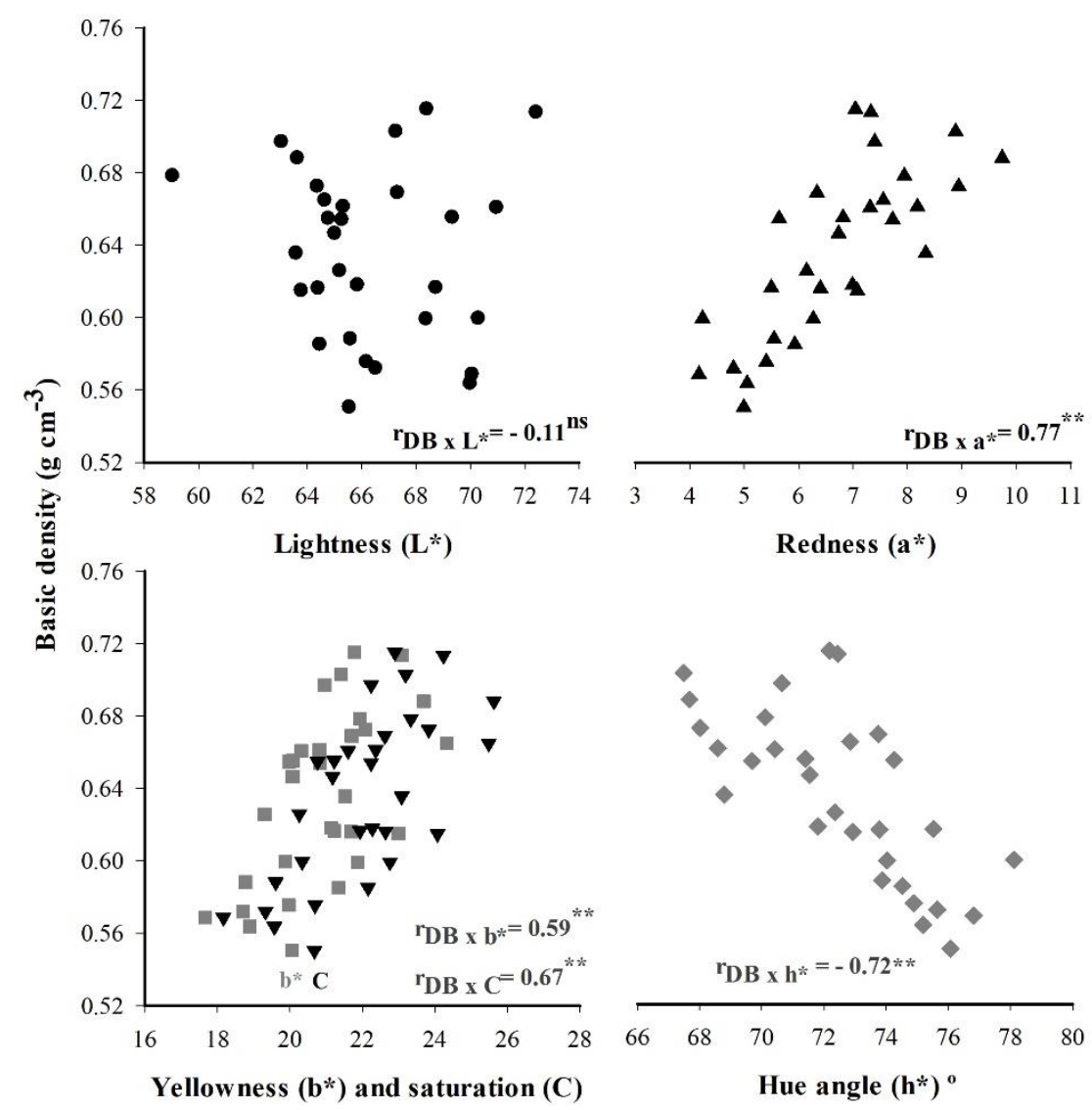

Legend: BD, basic density; ${ }^{\text {ns }}$, not significant $(\mathrm{p}>0.05)$; **, significant $(\mathrm{p}<0.01)$ by the F-test.

Figure 4. Correlations between the basic density and colorimetric parameters $\left(L^{*}, a^{*}, b^{*}, C^{*}\right.$ and $\left.h^{*}\right)$ of six-yearold Calycophyllum spruceanum wood.

Figura 4. Correlações entre a densidade básica e os parâmetros colorimétricos $\left(\mathrm{L}^{*}, \mathrm{a}^{*}, \mathrm{~b}^{*}, \mathrm{C}\right.$ e h*) da madeira de Calycophyllum spruceanum, com seis anos de idade.

\section{DISCUSSION}

\section{Colorimetric characterization of wood}

Regarding the evaluated colorimetric parameters (Table 1), it is noted that the effect of longitudinal position was radial dependent, and vice versa, since there was a significant interaction between these factors for $a^{*}, b^{*}, C$ and $h^{*}$ parameters, except for $L^{*}$, which was evaluated in isolation. The significant interaction between sampling positions expresses that the radial behavior of the colorimetric parameters may not be the same from the base to the top of the trees, which may decrease the standardization of sawn pieces from this species.

A striking feature in the color of this wood is the predominance of the yellowness $\left(b^{*}\right)$, also confirmed by the hue angle value ( $h *$ ) which was closest to the chromatic coordinate axis $b^{*}$ of the CIE-L* $a^{*} b^{*}$ system (1976). However, the small redness ( $\left.\mathrm{a}^{*}\right)$ also contributed to the original wood coloration as it is a primary color. The values of the $b^{*}$ and saturation $(C)$ parameters categorize the intrinsic pigmentation of the wood as a poorly concentrated yellow, which contributed to the yellowish-olive color. Regarding the brightness, the wood can be classified as high clarity, meaning with $\mathrm{L}^{*}>56$ (CAMARGOS; GONÇALEZ, 2001).

The wood colorimetric parameters of this study were quantitatively close to the values observed for the C. spruceanum wood native to the Peruvian Amazon, $\mathrm{L}^{*}=67.63 ; \mathrm{a}^{*}=5.34 ; \mathrm{b}^{*}=22.12 ; \mathrm{C}=22.76$; and $\mathrm{h}^{*}=$ 76.43 , obtained by Sotelo Montes et al. (2008). This quantitative analogy can also be observed with the tauari (Couratari oblongifolia) species: $\mathrm{L}^{*}=64.76 ; \mathrm{a}^{*}=6.21 ; \mathrm{b}^{*}=25.54 ; \mathrm{C}=26.28 ;$ and $\mathrm{h} *=76.32($ COSTA et al., 2011), and rubber tree (Hevea brasiliensis): $\mathrm{L}^{*}=77.55 ; \mathrm{a}^{*}=6.56 ; \mathrm{b}^{*}=19.61 ; \mathrm{C}=20.74 ;$ and $\mathrm{h}^{*}=71.74$, studied by Autran and Gonçalez (2006).

The colorimetric characterization precision of the C. spruceanum wood, as well as of other tropical species, practically enables classifying by combinations, which means to select sawn pieces of the same 
colorimetric pattern or in different shades for use on wood floors, in the manufacture of furniture or other products with higher added value (BARROS et al., 2014). This classification can be done during primary processing or after drying, considering the preference of the market or some specific niche regarding the wood color.

\section{Radial and longitudinal variability of wood color}

The presence of growth rings in the cross-section (Figure 1) increased the gray levels, causing a decrease in $\mathrm{L}^{*}$ and hues responsible for $\mathrm{a}^{*}$ and $\mathrm{b}^{*}$ coordinates, making the wood darker (GONÇALEZ et al., 2001). This effect can be explained by the proportion of late to early wood, since the first wood is formed by more juxtaposed cells with thick walls, relatively longer length and smaller diameter, which makes the ring darker. Considering that the proportion of late wood per area increases close to the bark, the higher density and lower lightness in this region are justified and may give rise to an inversely proportional relationship between these variables.

The variation behavior of the $\mathrm{a}^{*}, \mathrm{~b}^{*}$ and $\mathrm{C}$ colorimetric parameters (Table 2) is a reflection of the functional relationship between the colorimetric parameters, meaning that there was a directly proportional increase in yellowness $\left(b^{*}\right)$ and redness $\left(a^{*}\right)$ in the wood $\left[\mathrm{r}_{\mathrm{a}^{*} \times \mathrm{b}^{*}}=0.725(\mathrm{p}<0.01)\right]$, and together the saturation of these hues increased $\left[\mathrm{r}_{\mathrm{a}^{*} \mathrm{C}}=0.821\right.$ and $\left.\mathrm{r}_{\mathrm{b}^{*} \mathrm{x}}=0.988,(\mathrm{p}<0.01)\right]$. Atayde et al. . (2011) also observed a relationship between the colorimetric parameters, describing that as the $a^{*}$ and $b^{*}$ chromatic coordinates increase, the saturation values also increase.

For lightness (Figure 2), three trends of $\mathrm{L}^{*}$ variation along the commercial trunk were generally observed: i) a $9.92 \%$ decrease $\left(\Delta L^{*}=-6.29\right)$ in its base value for DBH, getting closer to gray in this position; ii) an increase of $5.24 \%\left(\Delta \mathrm{L}^{*}=3.32\right)$ in DBH up to $50 \%$ of commercial height; and iii) stabilization to the top of the tree. Less light was observed in the wood in the external position (Figure 2), tending to a more gray color. However, this percentage difference in the radial direction was very small, and it is not possible to distinguish it with the naked eye.

With the approximation of the base and bark of the commercial trunk, there was a higher concentration and saturation of redness in the C. spruceanum wood (Table 2), because the highest a* coordinate values were observed in the longitudinal positions of $0 \%$ and $\mathrm{DBH}$, and in the external radial position. The highest concentration and saturation for yellowness $\left(b^{*}\right)$ occurred in the DBH regions and in the external radial position. There were no differences for the red and yellowness between the positions of 75 and $100 \%$ of the commercial height and within them in the radial direction; however, the greatest longitudinal variability of these elements occurred in the external position, closest to the bark.

The closer to the peel, the greater the longitudinal variability of the hue angle, being uniform in the inner region near the medulla (Table 2). This variable was closer to the yellowness at the radial (intermediate and external) positions of the tree tops. There was a homogeneity in the medullary direction of the $\mathrm{h}^{*}$ values of the wood from 50\% of the commercial trunk. It can be considered that when sectioning the trees into two $3 \mathrm{~m}$ logs for an average commercial height of $6 \mathrm{~m}$, the wood from the first $\log$ has a greater $\mathrm{L}^{*}$ variation with a lighter colored end and a grayish end on the other.

The analyzed wood was young and yet the portions closer to the base have the largest amount of variation among the wood produced, which justifies the variability between the pigments. The produced portions have lighter colors (young wood) and less variability between pigmentation with the longitudinal growth of the tree. Regarding the radial portions, the closest to the medulla tends to have a smaller amount of extractives (LONGUI et al., 2010), presenting less variation among the evaluated discs. However, the variability was more evident in the outermost of the trunk.

\section{Relationship of extractives content to wood color}

The influence of extractives content on wood color (Figure 3), according to Moya et al. (2012), varies widely from species to species and is linked to the content of phenolic substances and heartwood formation, whose elements were not observed in the material under study. This may have contributed to the absence of these correlations.

According to Moya and Berrocal (2010), there is a significant correlation between some colorimetric parameters when analyzing the medulla-bark position; however, these authors only found significant correlations for the variation in the medulla color to the heartwood edges. In studying the color variation as a function of teakwood extractives content, Garcia and Marinonio (2016) found significant correlations for the $\mathrm{L}^{*}$ and $\mathrm{a}^{*}$ colorimetric parameters. These correlations were verified considering a data set including heartwood and sapwood, which have distinct characteristics of color and extractive content and type, indicating that the color variations that occur between heartwood and sapwood are linked to the biochemical and physiological changes which occur in extractives in the sapwood transformation into heartwood.

Therefore, the color formation of the C. spruceanum wood may be related to other extractives which are not removed in the extraction process, and thus may justify the absence of correlations. Another possible 
explanation may be the composite sampling of the trunk used in chemical analysis, because despite allowing to characterize the material, it generates few repetitions, and it is not possible to capture the effect of this property on wood color. Thus, it is recommended that further research with this species be developed, increasing the number of samples and repetitions to confirm the effect of extractives content on wood color.

\section{Relationship of basic density to wood color}

It is noteworthy that the hue angle was inversely proportional to the wood density (Figure 4), indicating that the denser regions of this species had the lowest $h^{*}$ values. By the CIE-L* $a^{*} b^{*}(1976)$ system, the smaller the $\mathrm{h}^{*}$, the closer it is to the chromatic coordinate axis $\mathrm{a}^{*}$, so the negative correlation between the hue angle and wood density can be a reflection of the positive relationship of this physical property to the red pigment.

Although with a low average value, the redness was the variable that best explained the relationship between the basic density and the $C$. spruceanum wood coloration; an effect superior to that of the yellow pigment, which is the main color-forming parameter of this species at the evaluated age. In estimating density as a function of wood color, the $\mathrm{a}^{*}$ coordinate together with $\mathrm{h} *$ are variable options which can contribute to the accuracy of the prediction models. For $C$. spruceanum wood aged 36 months, Sotelo Montes et al. (2008) mention that the correlation between density and some colorimetric parameters is very consistent for several tropical species. The authors observed a significant correlation between the basic wood density and the $\mathrm{L}^{*}, \mathrm{a}^{*}$ and $\mathrm{b}^{*}$ parameters, which although low indicated the increase of $\mathrm{L}^{*}$ with the decrease in the basic density and positive correlations for the $a^{*}$ and $b^{*}$ parameters.

This correlation pattern between colorimetric parameters and density was also found by Garcia and Marinonio (2016), who observed a negative correlation between $\mathrm{L}^{*}$ and density and a positive correlation between density and the a* parameter in an analysis of teak (Tectona grandis) sapwood alone. According to Garcia et al. (2014), dense Eucalyptus pellita woods are darker (smaller L*) in the radial section, while Eucalyptus paniculata woods presented more yellowness $\left(\mathrm{b}^{*}\right)$ in the tangential section. However, Mori et al. (2004) state that the basic density did not correlate with wood color parameters of Eucalyptus clones from 7.5 to 13.5 years old. The relationship between the basic density and the $a^{*}$ coordinate contributes to explain the higher red pigment concentration at the base and close to the bark of the $C$. spruceanum trunk, with these regions presenting a denser wood, and being in agreement with the results obtained by Garcia and Marinonio (2016).

\section{CONCLUSIONS}

The performed analyzes allow us to conclude that:

- The color of six-year-old C. spruceanum wood was classified as yellowish-olive, with a predominance of yellowness.

- The closer to the base and bark of the commercial trunk, the higher the concentration and saturation of red and yellow pigment in the $C$. spruceanum wood. The wood was lighter in regions closer to the bark and medulla.

- The extractives content at the age of six was not related to the wood color. The denser wood had higher yellow and red saturation and pigmentation.

- The colorimetric characterization of C. spruceanum wood contributes to a better grouping of sawn pieces, and can be used from the log splitting to the final use, adding commercial value to the wood.

\section{REFERENCES}

ARAÚJO, B. H. P.; SOUSA, M. A. R.; NASCIMENTO H. E. M.; ZANUNCIO, A. J. V.; RODRIGUES, D. M. S.; GUEDES, M. C. Propriedades físicas da madeira de Calycophyllum spruceanum Benth. em função do diâmetro e da posição (base e topo) no fuste. Scientia Forestalis, Piracicaba, v. 44, n. 111, p. 759-768, 2016.

ASSOCIAÇÃO BRASILEIRA DE NORMAS TÉCNICAS - ABNT. NBR 11941: Madeira - Determinação da densidade básica, Rio de Janeiro, 2003. 6p.

ATAYDE, C. M.; GONÇALEZ, J. C.; CAMARGOS, J. A. Características colorimétricas entre as seções anatômicas da madeira de muirapiranga (Brosimum sp.). Cerne, Lavras, v. 17, n. 2, p. 231-235, 2011.

AUTRAN, C. S.; GONÇALEZ, J. C. Caracterização colorimétrica das madeiras de Muirapiranga (Brosimum rubescens Taub.) e de Seringueira (Hevea brasiliensis, clone Tjir 16 Müll Arg.) visando à utilização em interiores. Ciência Florestal, Santa Maria, v. 16, n. 4, p. 445-451, 2006.

BARROS, S. V.; MUNIZ, G. I. B.; MATOS, J. L. M. Caracterização colorimétrica das madeiras de três espécies florestais da Amazônia. Cerne, Lavras, v. 20 n. 3, p. 337-342, 2014.

FLORESTA, Curitiba, PR, v. 49, n. 4, p. 803 - 812, out/dez 2019.

Silva, S. B. et.al.

ISSN eletrônico 1982-4688

DOI: $10.5380 /$ rf.v49 i4.59374 
CAMARGOS, J. A. A.; GONÇALEZ, J. C. A colorimetria aplicada como instrumento na elaboração de uma tabela de cores de madeira. Brasil Florestal, Brasília, n. 71, p. 30-42, 2001.

COSTA, J. A.; GONÇALEZ, J. C.; CAMARGOS, J. A. A.; GOMES, I. A. S. Fotodegradação de duas espécies de madeiras tropicais: jatobá (Hymenaea courbaril) e tauari (Couratari oblongifolia) submetidas à radiação ultravioleta. Cerne, Lavras, v. 17, n. 1, p. 133-139, 2011.

GARCIA, R. A.; MARINONIO, G. B. Variação da cor da madeira de teca em função da densidade e do teor de extrativos. Floresta e Ambiente, Seropédica, v. 23, n. 1. p. 124-134, 2016.

GARCIA, R. A.; OLIVEIRA, N. S.; NASCIMENTO, A. M.; SOUZA, N. D. Colorimetria de madeiras dos gêneros Eucalyptus e Corymbia e sua correlação com a densidade. Cerne, Lavras, v. 20, n. 4, p. 509-517, 2014.

GONÇALEZ, J. C.; JANIN, G.; SANTORO, A. C. S.; COSTA, A. F.; VALLE, A. T. Colorimetria quantitativa: uma técnica objetiva de determinar a cor da madeira. Brasil Florestal, n. 72, p. 47-58, 2001.

LONGUI, E. L.; LIMA, I. L.; SILVA JÚNIOR, F. G.; BUFOLO, A.; SUCKOW, I. M. S.; FLORSHEIM, S. M. B. Variação radial das características anatômicas, densidade aparente, teores de extrativos, lignina e holocelulose na madeira de Piptadenia gonoacantha (Mart.) Macbr. Scientia Forestalis, Piracicaba, v. 38, n. 87, p. $341-353$. 2010.

MARANHO, A. S.; PAIVA, A. V.; PAULA, S. R. P. Crescimento inicial de espécies nativas com potencial madeireiro na Amazônia. Revista Árvore, Viçosa, v. 37, n. 5, p. 913-921, 2013.

MORI, C. L. S. O; MORI, F. A.; LIMA, J. T.; TRUGILHO, P. F.; OLIVEIRA, A. C. Influência das características tecnológicas na cor da madeira de eucaliptos. Ciência Florestal, Santa Maria, v. 14, n. 2, p. 123-132, 2004.

MOYA, R.; BERROCAL, A. Wood colour variation in sapwood and heartwood of young trees of Tectona grandis and its relationship with plantation characteristics, site, and decay resistance. Annals of Forest Science, Paris, v. 67, n. 1, p. 109- 118, 2010.

MOYA, R.; FALLAS, R. S.; BONILLA, P. J.; TENORIO, C. Relationship between wood color parameters measured by the CIELab system and extractive and phenol content in Acacia mangium and Vochysia guatemalensis from fast-growth plantations. Molecules, Basel, v. 17, n. 4, p. 3639-3652, 2012.

PEIXOTO, H.; ROXO, M.; KOOLEN, H.; SIlVA, F.; SIlVA, E.; BRAUN, M. S.; WANG, X.; WINK, M. Calycophyllum spruceanum (Benth.), the Amazonian "tree of youth" prolongs longevity and enhances stress resistance in Caenorhabditis elegans. Molecules, Basel, v. 23, n.3, p. E534, 2018.

SANTOS, A.B.; RIBEIRO-OLIVEIRA, J.P.; CARVALHO, C.M. Sobre a botânica, a etnofarmacologia e a química de Calycophyllum spruceanum (Benth.) Hook. f. ex K. Schum). Revista Brasileira de Plantas Medicinais, Campinas, v.18, n.1, supl. 1, p.383-389, 2016.

SILVA, E. S.; STANGERLIN, D. M.; GATTO, D. A.; CALEGARI, L.; PARIZ, E. Colorimetria da madeira de oito espécies nativas do estado do Rio Grande do Sul, Brasil. Ciência da Madeira, Pelotas, v. 6, n. 1, p. 31-37, 2015.

SOTELO MONTES, C.; ROGER E. HERNÁNDEZ, R. E.; BEAULIEU, J.; WEBER, J . C. Genetic variation in wood color and its correlations with tree growth and wood density of Calycophyllum spruceanum at an early age in the Peruvian Amazon. New Forests, West Lafayette, v. 35, n. 1, p. 57-73, 2008.

TECHNICAL ASSOCIATION OF THE PULP AND PAPER INDUSTRY - TAPPI. Test methods T 257 om92: sampling and preparing wood for analysis. Atlanta: Tappi Technology Park, v.1, 1992.

UGARTE-GUERRA, L. J.; DOMÍNGUEZ-TORREJÓN, G. Índice de sitio (IS) de Calycophyllum spruceanum Benth. en relación con la altura dominante del rodal en ensayos de plantación en la Cuenca del Aguaytía, Ucayali, Perú. Ecología Aplicada, Lima, v. 9, n. 2, p. 101-111, 2010.

ZANUNCIO, A. J. V.; FARIAS, E. S.; SILVEIRA, T. A. Termorretificação e colorimetria da madeira de Eucalyptus grandis. Floresta e Ambiente, Seropédica, v. 21, n. 1, p. 85-90, 2014. 